\title{
Social Support and Preferred Values of the Unemployed with Varying Senses of Coherence
}

\begin{abstract}
The experience of losing a job is always a crisis situation. The condition for effective coping with unemployment is the mobilization of all available resources, among which the subjective psychological potentials of coping deserve special attention, and the sense of coherence, values and social support are particularly important.

The aim of the presented research was, therefore, to assess the relationship between social support for the unemployed and selected resources, which made it possible to create an image of the unemployed and their support with particular emphasis on the sense of coherence and the values preferred by them.
\end{abstract}

Keywords: unemployment, sense of coherence, values, social support, resources.

\section{Wsparcie społeczne a preferowane wartości i poczucie koherencji osób bezrobotnych}

\begin{abstract}
Abstrakt
Doświadczenie sytuacji utraty pracy stanowi zawsze sytuację kryzysową. Warunkiem skutecznego radzenia sobie w sytuacji bezrobocia jest mobilizacja wszystkich dostępnych zasobów, wśród których na szczególną uwagę zasługują podmiotowe potencjały radzenia sobie, a rolę szczególną przypisuje się poczuciu koherencji, wartościom i wsparciu społecznemu.
\end{abstract}

\footnotetext{
* Maria Curie Skłodowska University in Lublin, Faculty of Education and Psychology, Institute of Pedagogy.

** Maria Curie Skłodowska University in Lublin, Faculty of Education and Psychology, Institute of Pedagogy.
} 
Celem podjętych badań była zatem ocena zależności między wsparciem społecznym osób bezrobotnych a wybranymi zasobami, co pozwoliło na stworzenie obrazu bezrobotnego i jego wsparcia ze szczególnym uwzględnieniem poczucia koherencji oraz preferowanych przez niego wartości.

Słowa kluczowe: bezrobocie, poczucie koherencji, wartości, wsparcie społeczne, zasoby.

\section{Introduction}

Studies on the negative effects of unemployment on people have a long tradition. The experience of losing a job, which is important for satisfying the needs of an individual and their family, is always a crisis, one which forces an individual to cope in new conditions. For many people, unemployment is a difficult situation with a wide range of consequences. Therefore, psychological and social aspects of coping by the unemployed are a special area of consideration. A specific role in describing the phenomenon of unemployment is played by empirical studies, which analyse unemployment in terms of available subjective and social resources, such as the sense of coherence, preferred values, or social support, which may form various combinations of relationships.

In general, unemployment is the state of professional inactivity of people who are willing and ready to enter into gainful employment (Hajder 2008: 12; ref. to Mlonek 1992). In the literature, many various aspects of that phenomenon are identified. Most frequently, they are divided into economic, social-demographic, and political-legal ones (Wołk 2009; Miś 2007; Murawska 2015; Kabaj 2005; Nagel 2015; Fic 2015; Pilc 2014; Żółtaszek 2016). It is very difficult to describe all the negative consequences of unemployment, as they have different conditions (Kwiatkowski 2014: 77), concern the most important areas of people's functioning, i.e. the individual and the social (Wiatrowski 2005: 342), are related to each other, and their classifications are only symbolic. The experience of unemployment is modified depending on personality (Kirenko, Duda 2018; Skłodowski, Kucharski 2007: 203-204) and its nature results from an inability to satisfy one's needs.

Despite the possibly similar effects of the loss of a job, unemployment, and the long search for a job with no positive effects, the unemployed are as different as people with a job, as their psychological predispositions and social situations in which they live are different. As a result, the outlined range of problems occurs with various intensities and configurations in the case of different people (Kalbarczyk 2011: 105).

The reaction to the loss of a job depends on socio-demographic factors (sex, age, place of residence, social role played) (Kirenko, Duda 2018; Krajewski et al. 2010), the period of unemployment (Butterworth et al. 2012), attitudes, motivation to 
start working again (Murawska 2015; Nawrat 2001; Kirenko, Duda 2018), and individual and social resources (Kirenko, Duda 2018; Kirenko, Boczkowska 2017; Chudzicka 2004; Kowalczyk 2008; Ślebarska 2010).

Each individual with a positive attitude to work, related in a certain way to their job, and with personal predispositions (to become related to their job) sees the loss of a job and the fact of being unemployed as a personal life catastrophe and is more prone to various types of mental disorders (Śmilgin 2006: 428).

In addition, permanent and quick changes in the social space effectively increase the group of the unemployed. Individual consequences of unemployment include its negative effects on the performance of the care and educational function of the family (Lubińska-Bogacka 2011: 282, Hajder 2008: 11; Bejma 2015; Wolska-Długosz 2012), deterioration of health (Kulik et al. 2008; Latalski et al. 2003; Kostrzewski, Worach-Kardas 2008; Klonowicz 2001), including mental health (Brand 2015; Walczak 2000; Kalbarczyk 2011; Paul, Mosen 2009; Ishmuhametov, Palma 2017), deterioration of the quality of life (Kostrzewski, Worach-Kardas 2015; Balicki 2013; Zagożdżon, Ejsmont 2008), and a whole range of consequences related to the deterioration of one's lifestyle (more difficult access to health care services, no possibility of satisfying one's needs and purchasing goods; withdrawal from cultural life, realization of dreams and plans) (Juszczyk 2007; Drela 2015).

The considerations above show that work has a significant psychological meaning, as it satisfies the need of accomplishment, develops professional skills, stimulates interests, and defines requirements to be met, which supports an individual's mental health (Walczak 2000: 44).

The strategies of action with regard to unemployment, both preventive and supportive ones, are based on the support provided by job agencies, nongovernmental organizations, enterprise incubators, and careers advice institutions, which most frequently consist of financial aid or training.

Social policy followed in Poland focuses on solving the temporary and medium-term structural, economic, and social problems of the labour market through the market policy, which is passive (i.e. benefits) or active, i.e. one which generates new jobs (Żółtaszek 2016: 28; Flaszyńska 2019: 30-31).

The unemployment rate, which is still high, shows that those actions are not sufficient; that concerns material aid in particular, as shown in the study by B. Bieszk-Stolorz (2016). The results presented by her explicitly indicated that receipt of material aid by the unemployed extended the average period of unemployment and reduced the intensity of action aimed at entering into a new employment (Bieszk-Stolorz 2016: 46). 
Unemployment is a crisis, which causes stress, as "the unemployed functioning in society, in interaction with other people, are often in a difficult situation of deprivation, overburden, and risk" (Stochmiałek 2015: 82). The individual costs of unemployment depend, as a result, on many aspects, and the intensity of stress depends mainly on the cognitive assessment of the individual and their resources, both internal and external. The condition to cope effectively in the period of unemployment is to mobilize all available internal resources (those inside an individual) and external ones (those received from others). Among the resources available to an individual, special attention should be paid to the subjective, psychological potential of coping, defined as the "relatively permanent, dispositive, cognitive-affective, and behavioural-competence equipment of an individual, which performs its protective and stress-moderating functions by interfering in the processes of cognitive assessment and coping, the results of which may have a return influence on psychological resources of an individual or even change them" (Poprawa 2008: 104). A particular role in coping with stress is attributed to the sense of coherence, values, and social support (Bochniarz 2019; Poprawa 2008; Heszen, Sęk 2008), also in the case of the unemployed (Kirenko, Boczkowska 2017; Kirenko, Sarzyńska-Mazurek 2010).

Apart from optimism or mental resistance, the sense of coherence (Antonowsky 2005) plays a key role in coping with life difficulties and challenges (Heszen, Sęk 2008). It is a variable that remains in a close relationship with the personality structure of an individual and plays a control function with regard to other resources (it is a so-called meta-resource) (Terelak 2017: 418). It is the central category of the salutogenic model and it determines a special way of perceiving the surrounding world, which Antonovsky (2005: 34) defines as
a global orientation that expresses the extent to which one has a pervasive, enduring though dynamic feeling of confidence that the stimuli deriving from one's internal and external environments in the course of living are structured, predictable and explicable; the resources are available to one to meet the demands posed by these stimuli; these demands are challenges, worthy of investment and engagement.

That construct consists of three elements: the feeling of explicability, resourcefulness, and meaningfulness (Antonovsky 2005). The studies show that the higher the sense of coherence is, "the stronger the general positive attitude to oneself, one's life, and coping with one's life and other people is, and the stronger the belief in one's competence of coping and acting effectively is" (Poprawa 2008: 118 ), and that is why the sense of coherence is also one of the attributes of acting effectively in the workplace (Kirenko, Zubrzycka-Maciąg 2011). According to Antonovsky's concept (2005), a person with a high sense of coherence will use possible and available resources of coping with stress. It was found that the 
strongest relationship exists between coping with stress and the sense of resourcefulness. Based on the available literature, J. F. Terelak (2017: 418-419) described profiles of people with a strong (high) and weak (low) sense of coherence with regard to stress.

A person with a high sense of coherence assesses stimuli as not stressful, believes that problems can be solved, and recognizes them as clearer, more understandable, and possible to solve. If a stimulus is recognized as a stressor on the level of the cognitive assessment, a person with a high sense of coherence will treat it as a challenge which can be met. People with a strong sense of coherence focus on the instrumental aspect of a problem and select the most effective, according to them, ways of coping with stress. On the other hand, people with a weak sense of coherence more often see stress as a loss or a hazard. That is accompanied with a higher level of fear and depression, which correlates with anti-health behaviour (...) It was found, among other things, that people with a high sense of coherence more often exhibit the style focused on a task and more often seek social support; a weak sense of coherence is related to an emotional style of coping and a higher level of focus on distracting one's attention from the problem (intra-psychic processes).

In that context, it is worth underlining the role of the sense of coherence in getting and maintaining a job and in critical situations related to the loss of a job.

In the reality in which an individual lives, values perform an important regulatory role with regard to behaviours and, therefore, are an indisputable element of professional life. "Each person creates their own system of values, which is a hierarchic organization of beliefs concerning preferred manners of conduct and final goals of existence" (Kirenko, Wiatrowska 2015: 222). The system of values is developed from early childhood owing to the family, social contacts, peer groups, and institutions; it is related to the mental development of an individual. Therefore, it is obvious that values are an important element of a human personality. And so, values are

permanent beliefs that a specific manner of conduct or a final state of existence is personally or socially preferred as compared to an alternative manner of conduct or an alternative final state of existence. Values - beliefs concerning things which are demanded form a relatively permanent and hierarchic system. In this approach, a belief is a category defining values and, at the same time, a basic unit of a personality description (Rokeach after: Cieciuch 2013: 28).

Work is a value which stands high in an individual's hierarchy in each situation, also for the unemployed. In the studies by Derbis (2000: 218), work occupied the second place; it followed family and preceded money. It takes a high position 
among other values; however, it is not work related to development and selfrealization but that oriented more to financial benefits (Konopka 2011). Comparative studies also demonstrated significant differences concerning studied values between people with a job and the unemployed. The unemployed valued social prestige, strong position, well-being, religiousness, and tradition more. As opposed to people with a job, the unemployed held values related to their own accomplishments low. That may explain their situation as resulting from labour market conditions rather than their professional competences (Kirenko, Duda 2018: 171; cf. Kirenko, Boczkowska 2017), which indirectly demonstrates a relationship of higher aspirations and accomplishments of the unemployed with their situation in the labour market (Zalewska, Jaros 2008: 45).

An important role in the empirical analysis of unemployment is played by social support. It makes individuals believe that they are valuable, respected, and loved, which helps them to cope both with stressful situations and the challenges of everyday life. Support is a complex action which consists in experiencing received emotional, instrumental, and informational aid (Gottlieb, Bergen 2010: 512).

As a consequence of repeated observations and results of certain empirical studies, social support has started to be recognized as a buffer for negative results of life stress and critical events (Stochmiałek 2015: 157).

It involves a special kind of social interactions which are demonstrated in a diverse manner, i.e. from psychological to material aid, in the individual or group form. It is an intrinsic aspect of coping, in particular if an individual experiences a critical life event.

Support is described as a special manner and type of aid provided to individuals and groups mainly to mobilize their powers, potential, and resources, to enable them to cope with their problems on their own" (Kawczyńska-Butrym 1998: 87; ref. to Hobfoll 2006).

Therefore, the relationship between social support and unemployment is of a certain consequence, as the studies show that "the more support individuals receive, the more active they are in their efforts to find a job" (Ślebarska 2010: 164). As a result, it contributes to a more effective search for a new job. It is used to overcome the crisis caused by the loss of a job and becoming unemployed. That was confirmed, among other things, by studies by L. E. Waters and K. A. Moore (2002) on the relationship between self-assessment and support for the unemployed. The results show that higher social support is related to the self-assessment of the unemployed, both women and men, but a stronger relationship was observed in a group of unemployed women (Waters, Moore 2002: 180). However, what is most important is understanding the adequacy of the provided support to the needs of the unemployed. Support which is not adjusted to the situation of an unemployed 
person may bring results opposite to those intended (Sęk, Cieślak 2004; Chudzicka-Czupała 2004). That was in fact confirmed in the study by Ślebarska (2017: 111), where a significant relationship was demonstrated between adequate social support and pro-active coping; however, it was negative, which shows that the greater social support was received, the lower the level of pro-active coping was. The quantity of received support turned out to be inconsequential for the process of coping. The quoted research results have shown that social support may not be interpreted explicitly and the disputable role of social support requires more thorough empirical analyses.

The critical life event of unemployment and its characteristics have been the subjects of empirical studies for many years. A particular role in the analysis of that phenomenon is played by diverse personal conditions and resources of coping, in particular moderating resources, as knowledge in that area is an important element of designing actions aimed at the prevention of the negative consequences of unemployment and the effective return of the unemployed to professional activity. Many studies on that phenomenon consist in the analysis of social support and values of the unemployed; however, there are none concerning the relationship between those two variables in the area of the moderating role played by the sense of coherence.

Therefore, an answer was sought to the following research problem: what is the relationship between social support and the preferred values of the unemployed with a varying sense of coherence? The purpose of the study was to assess the relationship between social support of the unemployed and their sense of coherence as well as preferred values. The detailed questions concerned the determination of levels of preferred values of the unemployed and social support received by them. Questions were asked about the type of the sense of coherence and the relationships between preferred values in all the unemployed taking part in the study and their level of social support, within separate types of the sense of coherence.

Therefore, the general hypothesis was formed with regard to the questions about the relationships between the preferred values and the intensity of social support, which are different in separate dimensions of correlated variables, in particular in the people in whom different types of the sense of coherence are of a deciding consequence. It was assumed that the preferred values are positively related with social support and that the level of the sense of coherence moderates the relationship between the analysed variables in the group of the unemployed taking part in the study. Based on the empirical findings made so far, the following general hypothesis was formed:

H1: Social support has a positive relationship with the preferred values of the unemployed, with the moderating role of the sense of coherence. In people with a low sense of coherence, the relationship between those variables is stronger (and positive) than in people with a high sense of coherence. 
According to the findings made to date, it is assumed that the unemployed have a lower level of subjective resources in coping with a difficult situation; therefore, they have a lower level of coherence significantly more often and, as a result, they need social support in all possible aspects. On the other hand, people with a higher sense of coherence cope with challenges and the situation of unemployment more effectively and, as a result, they do not require more intensive resources of support. That is a consequence of the nature of the studied phenomenon and the relationships between the variables.

\section{Method}

The research material was collected using the diagnostic survey method, which consisted of the following research tools: the Social Support Questionnaire (SSQ) by J. S. Norbeck adapted by Kirenko (experimental version), the Portrait Value Questionnaire (PVQ-R2 - S. Schwartz - Polish adaptation by Cieciuch), and the Sense of Coherence Questionnaire (SOC-29 - Antonowsky, Polish adaptation by teams from the Clinical Psychology Department of the Institute of Psychiatry and Neurology in Warsaw, the Department of Psychological Prevention of the Institute of Psychology of the Adam Mickiewicz University in Poznań, and the Department of the Occupational Psychology of the Institute of Occupational Medicine in Lodz).

The Social Support Questionnaire by J. S. Norbeck makes it possible for the researcher to describe the resources of social support and provides information on people giving social support in a social network by providing emotional and instrumental aid to an individual in their efforts to overcome a difficult situation. It consists of three parts: the first part includes information on the source groups of support identified by the subject, ones who play a significant or important role in the subject's life, and the second part consists of eight questions concerning the people identified in the first part. The third part of the questionnaire concerns "the frequency of contacts, the duration of the relationship, and the information on the loss of a close relative in the preceding year" (Kirenko, Lesiewicz, 2002: 82). The subject answers each question using a 5-point Likert scale. The Portrait Value Questionnaire (PVQ-R2 S. Schwartz), on the other hand, consists of 57 statements and involves descriptions of various people, measuring preferences of ten categories of values which are also called types: self-direction $(K)$, stimulation $(S)$, hedonism $(\mathrm{H})$, achievement $(0)$, power $(\mathrm{W})$, universalism $(\mathrm{U})$, benevolence $(\dot{\mathrm{Z}})$, conformity $(\mathrm{P})$, tradition $(\mathrm{T})$, and security $(\mathrm{N})$. The reliability indices of the questionnaire scales are 0.71 to 0.80 (Cronbach's alpha). With regard to the moderating variable, the Sense of Coherence Questionnaire (SOC-29) by Antonovsky was used. It consists of 29 statements to which answers are given according to the estimation scale (scores from 1 to 7 ). Apart from the general score 
of the sense of coherence, it enables researchers to determine the level of its components, i.e. the sense of comprehensibility (PZR), the sense of manageability (PZ), and the sense of meaningfulness (PS). The questionnaire contains satisfactory psychometric properties; the reliability index of the global result is $\mathrm{rtt}=0.92$, Cronbach's alpha $=0.78$. An original interview questionnaire was also used.

Overall, 236 unemployed people took part in the study, out of which 148 people received unemployment benefit and 88 people were not entitled to receive the benefit. The analysis of the data shows that women were a slight majority in the group (55.93\%, while men only $44.07 \%$ ). The largest part of the group was composed of married people (52.12\%); 82 people were not married (mostly women, i.e. $76.83 \%$ of that group), while only $13.14 \%$ of the whole studied group were widows or widowers. The largest age group was composed of the subjects aged below 30, i.e. 129 people. There were 51 subjects aged $31-40$ and 36 subjects aged up to 50. 20 people were above 51. Most subjects had completed higher education (34.32\%), followed by secondary occupational education $(22.17 \%)$, general secondary and post-secondary education (each group at 12.29\%), occupational education (10.17\%) and elementary or incomplete elementary education (8.9\%). A majority of the subjects were city residents (136 people). As many as 35 subjects declared that they had no income or any means to support themselves. Most frequently, the unemployed declared that their main means of support included the work of their spouse (38.98\%). 41 people earned their income from illegal work and $11.02 \%$ of the subjects received financial aid from their family, while $9.42 \%$ received social aid (the result shows that people entitled to receive the benefit do not treat that money as social aid). 15 people received a disability pension (6.36\%) and 8 people declared their own salary as a means of support. Other resources were used by $7.63 \%$ of the unemployed (unfortunately, they did not provide any details concerning their sources of income). The subjective assessment of the level of income and, what follows, the material situation was low. Over $61.86 \%$ people found their own material situation very bad, bordering on poverty, as their incomes were not sufficient to satisfy their fundamental needs. Only one in three subjects confessed that they had sufficient money to buy everything they needed; only $2.54 \%$ of the subjects were satisfied with their standard of living. That translated into an average monthly income of the family - 176 unemployed, i.e. 74.57\% of the studied group, received less than PLN 500; an average income of PLN 600-1000 was earned by 48 people, and one person declared their average income to be PLN 1,500. Considering the fact that the most people declared that they shared their household with one person or two people (94.64\%), that low assessment of their material resources was very probable. 


\section{Results}

It was possible to determine the types of the sense of coherence in the studied unemployed owing to the determination of the nature of their hierarchically organized structures, which was achieved using k-means clustering. As a result, three clusterings were found (Chart 1).

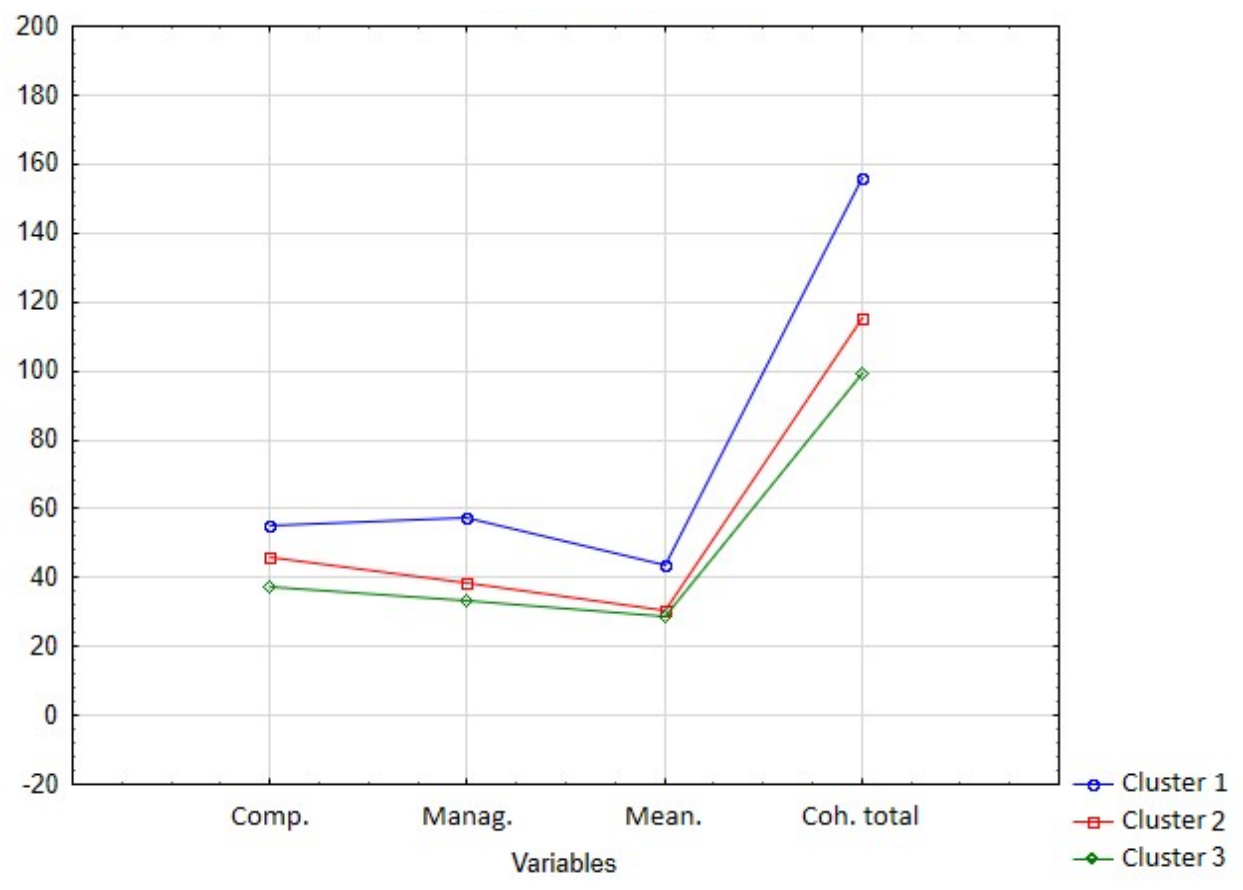

Chart 1. Types of the sense of coherence of the studied unemployed

Source: original work.

The configurations of the three components of the sense of coherence in the presented study are not similar. They differ in the intensity of the analysed components, which translates into the specificity of the separated groups of the studied unemployed. It is worth mentioning that the obtained clustering profiles are highly stable. The highest level of the sense of coherence in all analysed components is in clustering no. 1 , which is composed of 43 people. That is the type with the high sense of coherence (W). These are people with the significantly highest level of resourcefulness, which is a significant factor correlated positively with coping (Pasikowski 2000). Therefore, those are people who cope best in the situation of stress, perceiving their situation as a challenge and problem which it is possible to solve and worth their dedication. The second clustering where the result of meaningfulness coincides with the third clustering is composed of the 
largest number of the unemployed (105 people); it is the type with the average level of the sense of coherence (P). Those are the unemployed who tend to react emotionally in the face of a difficult situation; they perceive their situation as a hazard and have a low sense of meaningfulness, which shows that they have difficulties with understanding their own situation and show a lower level of dedication to solving the problem. The unemployed people who form the third clustering react in a similar way, as the results of their components are similar. Those are the people with the lowest sense of coherence (clustering no. 3). It is composed of 88 people with a low (weak) sense of coherence (N) in all components. The unemployed from this group perceive the situation of their unemployment as a hazard; they use strategies focused on emotions more frequently, show worse coping both in new and in well-known problematic situations, and do not make any attempts at solving their problem. Furthermore, they have difficulties with seeing meaning in their situation and demonstrate a low dedication to overcoming their difficulties, as they treat them as unworthy of any effort (Chart 1) (cf. Chirkowska-Smolak 2000: 164).

The levels of social support, in its three dimensions and the functional sum, as well as values with various levels of the sense of coherence were determined using one-way analysis of variance (ANOVA), the results of which are presented in Tables 1-2.

Social support helps to accomplish the adopted goals and cope with stress. In the case of social support directed to the unemployed, it is necessary to adjust the support itself and its amount so as not to make coping with the situation of returning to the labour market more difficult. The presented results of analyses show significant differences in each analysed dimension of social support between the unemployed with the various intensities of the sense of coherence (Table 1).

Table 1. Social support of the studied unemployed with a various sense of coherence - ANOVA

\begin{tabular}{|l|c|c|c|c|}
\hline \multicolumn{1}{|c|}{ Variables } & $\mathrm{F}$ & \multicolumn{3}{c|}{ Intra-group comparison } \\
\hline Emotions (E) & $9.66^{*}$ & $\{\mathrm{~W}\} 29.26$ & $\{\mathrm{P}\} 39.42^{*}$ & $\{\mathrm{~N}\} 43.14^{*}$ \\
\hline Affirmation (AF) & $8.66^{*}$ & $\{\mathrm{~W}\} 28.61$ & $\{\mathrm{P}\} 38.38^{*}$ & $\{\mathrm{~N}\} 41.11^{*}$ \\
\hline Aid (PO) & $9.65^{*}$ & $\{\mathrm{~W}\} 30.51$ & $\{\mathrm{P}\} 42.42^{*}$ & $\{\mathrm{~N}\} 45.73^{*}$ \\
\hline Functional sum (SF) & $9.64^{*}$ & $\{\mathrm{~W}\} 88.39$ & $\{\mathrm{P}\} 120.24^{*}$ & $\{\mathrm{~N}\} 129.99^{*}$ \\
\hline
\end{tabular}

Source: the author's original work. ${ }^{*}-\mathrm{p}<0.05$.

The received values of the $\mathrm{F}$ test for three groups compared at the same time with regard to the sense of coherence are statistically significant, which makes it possible to confirm that there is a significant relationship between the three categories and the functional sum of social support, and the sense of coherence in the studied unemployed. The highest level of the sense of social support, both in the 
area of emotions, affirmation, and aid, and the functional sum, was found in the unemployed with a low sense of coherence. The emotions show an individual attitude to the surrounding reality and the intensity of experiences. The studied unemployed differ significantly with regard to the intensity of the sense of coherence. People with average or low sense of coherence experience intense emotions. That indicates the intensity of experiences. The high result of the group of the unemployed with a low level of coherence shows strong emotional reactions in the face of a crisis and, at the same time, a strong need for social support. The high result concerning affirmation is also characteristic of people with a low sense of coherence. That shows a strong need for support which is demonstrated with the need of acceptance by people who are closest to an individual. Those individuals also have the strongest relationship with their social group; they receive help and trust. The category of aid also has the highest results for the group with a low sense of coherence, which may indicate great help received from their closest family members and friends. The total result showing the support received from significant others is also very diverse for the studied unemployed. The greatest support is received by people with the lowest sense of coherence.

The results of the study explicitly show that the studied unemployed with a low sense of coherence receive significantly higher social support in all studied dimensions. Therefore, it should be stated that the low sense of coherence correlates significantly with the need for social support in all studied aspects, i.e. emotions, affirmation, and aid. That shows that there is a greater tendency to support the unemployed with a low sense of coherence. It may also be a result of the fact that people with a high sense of coherence and a high sense of resourcefulness see their situation as possible to solve, which favours more effective ways to cope with stress. Social support is a positive resource for them, but it does not decide about their situation. People with a low sense of coherence, on the other hand, focus strongly on emotions and searching for help, and have a strong need for acceptance, which generates a higher need for social support. Such an attitude stimulates their community to provide high levels of support, which makes coping with unemployment and the active search for a job effectively more difficult.

A significant statistic relationship between emotional, affirmative, and aidrelated social support and the sense of coherence in the studied unemployed shows that support is received more often in the group of people with the low level of coherence.

The preferred values were compared between people with various intensities of the sense of coherence (Table 2). The results of the F test for the compared group of the unemployed, which were greater than the critical value at its highest level and which made it possible to perform intra-group comparisons, were found in nine categories of values, which shows a significant relationship between the preferred values and the sense of coherence of the studied unemployed. 
Table 2. Categories of values of the studied unemployed with varying sense of coherence - ANOVA

\begin{tabular}{|l|c|c|c|c|}
\hline \multicolumn{1}{|c|}{ Variables } & $\mathrm{F}$ & \multicolumn{3}{c|}{ Intra-group comparison } \\
\hline Self-direction (K) & $3.35^{*}$ & $\{\mathrm{~W}\} 22.19^{*}$ & $\{\mathrm{P}\} 20.70$ & $\{\mathrm{~N}\} 19.37$ \\
\hline Stimulation (S) & $14.91^{*}$ & $\{\mathrm{~W}\} 13.87^{*}$ & $\{\mathrm{P}\} 10.32$ & $\{\mathrm{~N}\} 9.55$ \\
\hline Hedonism (H) & $8.00^{*}$ & $\{\mathrm{~W}\} 13.92^{*}$ & $\{\mathrm{P}\} 11.72$ & $\{\mathrm{~N}\} 10.79$ \\
\hline Achievements (O) & $3.24^{*}$ & $\{\mathrm{~W}\} 17.75^{*}$ & $\{\mathrm{P}\} 16.72$ & $\{\mathrm{~N}\} 15.77$ \\
\hline Power $(\mathrm{W})$ & $4.52^{*}$ & $\{\mathrm{~W}\} 11.95^{*}$ & $\{\mathrm{P}\} 9.51$ & $\{\mathrm{~N}\} 9.90$ \\
\hline Universalism (U) & 0.37 & $\{\mathrm{~W}\} 35.53$ & $\{\mathrm{P}\} 35.19$ & $\{\mathrm{~N}\} 34.36$ \\
\hline Benevolence (Z) & $4.74^{*}$ & $\{\mathrm{~W}\} 24.43^{*}$ & $\{\mathrm{P}\} 24.20^{*}$ & $\{\mathrm{~N}\} 22.29$ \\
\hline Adaptation (P) & $4.31^{*}$ & $\{\mathrm{~W}\} 20.34^{*}$ & $\{\mathrm{P}\} 19.26^{*}$ & $\{\mathrm{~N}\} 17.89$ \\
\hline Tradition (T) & $6.55^{*}$ & $\{\mathrm{~W}\} 19.02^{*}$ & $\mathrm{P}\{\} 16.27$ & $\{\mathrm{~N}\} 16.08$ \\
\hline Security (B) & $4.69^{*}$ & $\{\mathrm{~W}\} 26.24^{*}$ & $\{\mathrm{P}\} 24.20$ & $\{\mathrm{~N}\} 23.39$ \\
\hline
\end{tabular}

Source: original work. ${ }^{*}-\mathrm{p}<0.05$.

It turns out that almost all categories of values significantly diversify the studied groups in favour of people with a high sense of coherence. Universalism was an exception, as its result was insignificant statistically and the average values were similar in all studied groups. The highest results were obtained by people with a high (strong) sense of coherence. Therefore, it should be stated that the studied unemployed with a high sense of coherence as compared to the other studied groups, in particular to people with a low sense of coherence, prefer significantly more often values related to respect, acceptance, involvement in celebrating customs and culture, status, and social prestige. Therefore, it should be indicated that people who understand their own situation, use their own resources to help themselves, and see their own life situation as worthy of effort show high levels of dedication to giving value to life and being driven by values in their everyday life. They identify themselves with values to a greater extent and they hold values, in particular ones related to their own security, the security of their closest relatives, and the freedom in directing oneself and one's choices, in high regard. They also respect values related to pleasures, achievements, and power to a significant extent, but with a slightly lower intensity than people with an average sense of coherence. People from the group with a low sense of coherence appreciate all the analysed values significantly more rarely. People with a high sense of coherence believe that values play a great role in their life and they identify themselves with values significantly more frequently than the remaining groups.

A special role in the description of the phenomenon of unemployment is played by empirical studies analysing unemployment as to available subjective and social resources. Using multiple regression analysis, relationships were characterised between factors of dependent variables, i.e. social support, and independent variables, i.e. values, in the studied groups of the unemployed, and its 
areas, i.e. three types of the sense of coherence, all the more so as they have been confirmed during inter-correlation analyses ${ }^{1}$. On the level of variables, the model was satisfactorily adapted to empirical data. Regression models of the social support variable in the studied group and the sub-groups separated in the analysis with regard to the sense of coherence, together with factors of determination and multiple correlation are presented in Table 3.

People with a high assessment of their own possibilities and valuing openness to change highly do not require social support focused on emotions. In the event of support in the form of affirmation, people experiencing it need the feeling that they are an object of tolerance for themselves and for others; however, they do not show openness in action. The unemployed focused on obtaining help from their closest relatives value pleasure and comfort in particular and show adaptation to the situation rather than active coping. In the group of the studied unemployed, it was the value showing appreciation of openness to changes and freedom of thinking that had the largest share, on the statistically significant level or on the level close to statistically significance, in the result variation for the social support variable, which shows that independent people do not need social support in all analysed dimensions. The most interesting and complicated model of relationships between the studied variables concerned people with a low sense of coherence. Those individuals show, in particular, values related to stimulation, subordination, and tolerance; as a consequence, they need emotional support. However, that support correlates negatively with the freedom of thinking, trust, and cultivating tradition. A similar distribution of values concerned other dimensions of support. That indicates that people who experience or need support demonstrate conservatism and adaptation. On the other hand, the values related to openness and strengthening oneself show a negative relationship with support, which indicates low demand for support or low levels of support received.

Table 3. Results of multiple regression analysis: results of the social support variable and independent values variables and a sense of coherence in the studied groups

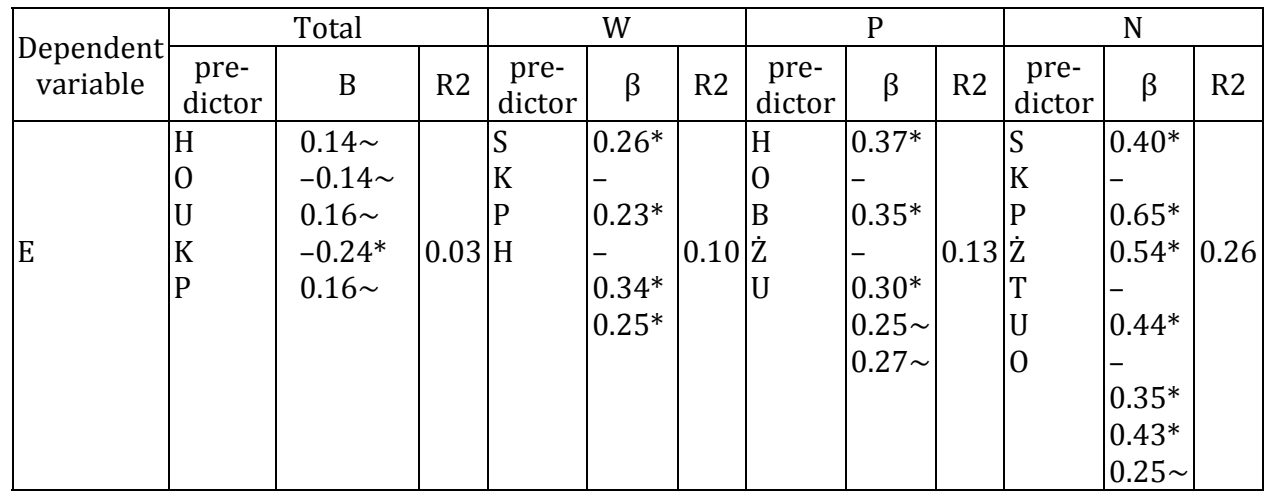

${ }^{1}$ Due to the limited space, the tables were not included. 


\begin{tabular}{|c|c|c|c|c|c|c|c|c|c|c|c|c|}
\hline $\mathrm{AF}$ & $\begin{array}{l}\mathrm{H} \\
\mathrm{K} \\
\mathrm{U}\end{array}$ & \begin{tabular}{|l|}
$0.15^{*}$ \\
$-0.30^{*}$ \\
$0.19^{*}$
\end{tabular} & 0.04 & $\begin{array}{l}\mathrm{S} \\
\mathrm{K} \\
\mathrm{W} \\
0 \\
\dot{\mathrm{Z}}\end{array}$ & \begin{tabular}{|l}
$0.31^{*}$ \\
- \\
$0.28^{*}$ \\
$0.29^{*}$ \\
$0.33^{*}$ \\
$0.21 \sim$
\end{tabular} & 0.10 & $\begin{array}{l}\mathrm{H} \\
\mathrm{O} \\
\mathrm{Z} \\
\mathrm{K} \\
\mathrm{U} \\
\mathrm{T}\end{array}$ & \begin{tabular}{|l|}
$0.40^{*}$ \\
- \\
$0.24 \sim$ \\
$0.30^{*}$ \\
- \\
$0.31^{*}$ \\
$0.43^{*}$ \\
- \\
$0.25 \sim$
\end{tabular} & 0.11 & $\begin{array}{l}\text { S } \\
\text { K } \\
P \\
\dot{Z} \\
T \\
\text { U } \\
0\end{array}$ & \begin{tabular}{|l|}
$0.39^{*}$ \\
- \\
$0.68^{*}$ \\
$0.51^{*}$ \\
- \\
$0.38^{*}$ \\
- \\
$0.32^{*}$ \\
$0.43^{*}$ \\
$0.28 \sim$
\end{tabular} & 0.27 \\
\hline PO & $\begin{array}{l}\mathrm{H} \\
\mathrm{K} \\
\mathrm{P} \\
\mathrm{U}\end{array}$ & \begin{tabular}{|l|}
$0.18^{*}$ \\
$-0.25^{*}$ \\
$0.17^{*}$ \\
$0.15 \sim$
\end{tabular} & 0.03 & $\begin{array}{l} \\
0 \\
T \\
\text { T }\end{array}$ & {$\left[\begin{array}{l}0.29^{*} \\
0.31^{*} \\
- \\
0.28^{*} \\
- \\
0.26^{*}\end{array}\right.$} & $\begin{array}{l}0.09 \\
0.09\end{array}$ & $\begin{array}{l}\mathrm{H} \\
\mathrm{O} \\
\dot{\mathrm{Z}} \\
\mathrm{T} \\
\mathrm{P}\end{array}$ & $\begin{array}{l}0.42^{*} \\
- \\
0.28^{*} \\
0.24 \sim \\
- \\
0.31^{*} \\
0.27 \sim\end{array}$ & $\begin{array}{l}0 \\
0.10\end{array}$ & $\begin{array}{l} \\
K \\
P \\
\dot{Z} \\
U \\
T \\
\mathrm{~T} \\
S\end{array}$ & \begin{tabular}{|l|}
$0.46^{*}$ \\
- \\
$0.64^{*}$ \\
$0.48^{*}$ \\
- \\
$0.45^{*}$ \\
$0.52^{*}$ \\
- \\
$0.33^{*}$ \\
$0.23 \sim$ \\
\end{tabular} & 0.27 \\
\hline SF & $\begin{array}{l}\mathrm{H} \\
\mathrm{K} \\
\mathrm{U}\end{array}$ & \begin{tabular}{|l|}
$0.17^{*}$ \\
$-0.27^{*}$ \\
$0.14 \sim$
\end{tabular} & $\begin{array}{l} \\
0.03\end{array}$ & $\begin{array}{l}\mathrm{S} \\
\mathrm{K} \\
\dot{Z} \\
\mathrm{P} \\
\mathrm{U} \\
\mathrm{H}\end{array}$ & \begin{tabular}{|l|}
$.28^{*}$ \\
- \\
$0.25^{*}$ \\
$0.22 \sim$ \\
- \\
$0.36^{*}$ \\
$0.27^{*}$ \\
$0.33^{*}$
\end{tabular} & $\begin{array}{l} \\
0.11\end{array}$ & $\begin{array}{l}\mathrm{H} \\
\mathrm{O} \\
\mathrm{Z} \\
\mathrm{B} \\
\mathrm{U}\end{array}$ & $\begin{array}{l}0.41^{*} \\
- \\
0.29^{*} \\
0.30^{*} \\
- \\
0.23 \sim \\
0.33^{*}\end{array}$ & 0.12 & $\begin{array}{l}\text { S } \\
\mathrm{P} \\
\mathrm{K} \\
\dot{\mathrm{Z}} \\
\mathrm{O} \\
\mathrm{U} \\
\mathrm{T}\end{array}$ & \begin{tabular}{|l|}
$0.33^{*}$ \\
$0.52^{*}$ \\
$0.66^{*}$ \\
- \\
$0.43^{*}$ \\
$0.34^{*}$ \\
$0.47^{*}$ \\
- \\
$0.34^{*}$ \\
\end{tabular} & 0.28 \\
\hline
\end{tabular}

Source: original work. ${ }^{*}-\mathrm{p}<0.05 ; \sim$ - close to significance.

\section{Results and discussion}

Support is an important factor of active coping with unemployment; however, their relationship is still disputable (Ślebarska 2010, 2017). The presented results prove that there is a relationship between the sense of coherence and social support.

The studies and presented results demonstrate the significance of the sense of coherence in the studied group of the unemployed (Chirkowska-Smolak 2000: 164, Werner 2009) and its determining role in the adequacy of the provided social support (Ślebarska 2010, 2017). The results concerning the sense of coherence are in line with the findings of other researchers who searched for relationships between that variable and manners and efficiency of coping in a difficult life situation. The important role of the sense of resourcefulness has been confirmed, as it showed the highest positive correlation with coping with stress (Terelak 2017). However, the assumption that people with a high sense of coherence seek social 
support (Terelak 2017) was not quite reflected in the presented studies. It turns out that people with various types of the sense of coherence prefer different values and expect different social support. Therefore, the study enabled us to create an image of an unemployed person and support for them, considering their sense of coherence and the values they prefer. The obtained results show how important the role played by the sense of coherence is in adjusting the type and quantity of social support. Based on the presented study, it may be stated initially that working on a high sense of coherence will lead to intensified pro-active behaviours and reduce the need for social support, as it gives a positive potential for coping with life events (Jarmużek 2018: 46). That confirms the fact that the sense of coherence, being a meta-resource (Antonovsky 2005: 19; Poprawa 2008), becomes not only a foundation for the development of other personal resources, but also, as a result, increases one's chances of getting and keeping a job and for coping with unemployment (Pasikowski 2000: 34-57). In conclusion, the presented empirical study confirmed the hypothesis about the positive relationship between social support and preferred values of the unemployed with a low sense of coherence.

The study was conducted with a relatively small number of unemployed individuals participating; however, the obtained results were sufficient to verify the hypothesis statistically and, therefore, their role as a reconnaissance should be emphasized. Further analyses should focus on a wider range of socio-demographic variables and treat them as detailed predictors of the assumed empirical undertakings. The role of the sense of coherence as well as social support and values in mental and social functioning of the unemployed needs a more thorough analysis, as we have to be aware that the obtained results were influenced by variables which were not examined in this study.

\section{References}

Antonowsky A. (2005) Rozwikłanie tajemnicy zdrowia. Jak radzić sobie ze stresem i nie zachorować?, transl. by H. Grzegołowska-Klarkowska, Warszawa, Wydawnictwo Fund. Instytutu Psychiatrii i Neurologii.

Balicki M. (2013) Praca - fundamentalnq wartościq jakości życia in: W poszukiwaniu jakości życia. Ujęcie interdyscyplinarne, Jasiński M. (ed.), Białystok, Niepaństwowa Wyższa Szkoła Pedagogiczna: 339-352.

Bejma U. (2015) Bezrobocie jako dysfunkcyjny czynnik małżeńsko-rodzinnego życia we współczesnej rodzinie polskiej, "Pieniądze i Więź”, 3 (68): 111-119.

Bieszk-Stolorz B. (2016) Wybrane modele przeciętnego efektu oddziaływania w analizie procesu wychodzenia z bezrobocia, "Prace Naukowe Uniwersytetu Ekonomicznego we Wrocławiu", 427: 40-48. 
Bochniarz A. (2019) Psychospołeczne uwarunkowania potrzeb młodzieży z rodzin niepełnych, Lublin, Wydawnictwo UMCS.

Brand J. E. (2015) The Far-Reaching Impact of Job Loss and Unemployment, "Annual Review of Sociology", 41: 359-375.

Butterworth P., Leach L.S., Pirkis J., Kelaher M. (2012) Poor mental health influences risk and duration of unemployment: a prospective study, "Social Psychiatry and Psychiatric Epidemiology", 47, 6: 1013-1021.

Chirkowska-Smolak T. (2000) Aktywność bezrobotnych w świetle psychologicznych modeli poszukiwania pracy, "Ruch Prawniczy, Ekonomiczny i Socjologiczny", LXII, 4: 147-166.

Chudzicka-Czupała A. (2004) Bezrobocie. Różne oblicza wsparcia, Katowice, Wydawnictwo Uniwersytetu Śląskiego.

Cieciuch J. (2013) Pomiar wartości w zmodyfikowanym modelu Shaloma Schwartza, "Psychologia Społeczna", 8, 1 (24): 22-41.

Derbis R. (2000) Doświadczanie codzienności, Częstochowa, Wydawnictwo WSP.

Drela K. (2015) Socjologia i inne nauki o pracy i bezrobociu, Part II, "Zeszyty Naukowe. Firma i Rynek", 1 (48): 75-86.

Fic M. (2015) Niedopasowanie kwalifikacji i bezrobocie ludzi młodych w Unii Europejskiej, "Problemy Profesjologii", 2: 53-65.

Flaszyńska E. (2019) Bezrobocie - bezrobotny - praca socjalna, Warszawa, Wydawnictwo Difin SA.

Gottlieb B. H., Bergen A. E. (2010) Social support concepts and measures, "Journal of Psychosomatic Research", 69: 511-520.

Hajder K. (2008) Wybrane uwarunkowania rozwoju bezrobocia w Polsce, Poznań, Wydawnictwo Naukowe WNPiD UAM.

Heszen I., Sęk H. (2008) Psychologia zdrowia, Warszawa, Wydawnictwo Naukowe PWN.

Ishmuhametov I., Palma A. (2017) Unemployment as a Factor Influencing Mental WellBeing, "Procedia Engineering", 178: 359-367.

Hobfoll S. E. (2006) Stres, kultura i społeczność. Psychologia i filozofia stresu, transl. by M. Kacmajor, Sopot, Gdańskie Wydawnictwo Psychologiczne. 
Jarmużek J. (2018) Poczucie koherencji a aktywność edukacyjna dorosłych. Studium teoretyczno-badawcze, Poznań, Wydawnictwo Naukowe UAM.

Juszczyk S. (2007) Problem bezrobocia $w$ świetle inwestycji infrastrukturalnych na obszarach wiejskich, Piotrków Trybunalski, Naukowe Wydawnictwo Piotrkowskie przy Filii Akademii Świętokrzyskiej.

Kabaj M. (2005) Ekonomia tworzenia i likwidacji miejsc pracy. Dezaktywizacja Polski?, Warszawa, IPiSS.

Kalbarczyk A. (2011) Metody efektywnej pomocy psychologicznej w pracy doradcy zawodowego z osobq bezrobotnq, Warszawa, Ministerstwo Pracy i Polityki Społecznej.

Kawczyńska-Butrym Z. (1998) Niepełnosprawność - specyfika pomocy społecznej, Katowice, Wydawnictwo Naukowe "Śląsk".

Kirenko J., Boczkowska M. (2017) Bezrobocie - Zachowania zdrowotne - Uwarunkowania, Lublin, Wydawnictwo UMCS.

Kirenko J., Duda M. (2018) Bezrobocie - Jakość życia - Uwarunkowania, Lublin, Wydawnictwo UMCS.

Kirenko, J. Lesiewicz, L. (2002) Wykorzystanie Kwestionariusza Wsparcia Społecznego $w$ badaniu osób niepełnosprawnych in: Problemy pedagogiki specjalnej $w$ okresie przemian społecznych, A. Pielecki (ed.), Lublin, Wydawnictwo Uniwersytetu Marii Curie-Skłodowskiej: 75-88.

Kirenko J., Sarzyńska-Mazurek E. (2010) Bezrobocie, niepełnosprawność, potrzeby, Wydawnictwo UMCS, Lublin.

Kirenko J., Wiatrowska A. (2015) Otyłość. Przystosowanie i uwarunkowania, Lublin, Wydawnictwo UMCS.

Kirenko J., Zubrzycka-Maciąg T. (2011) Współczesny nauczyciel. Studium wypalenia zawodowego, Lublin, Wydawnictwo UMCS.

Klonowicz T. (2001) Stres bezrobocia, Warszawa, Wydawnictwo Instytutu Psychologii PAN, Szkoła Wyższa Psychologii Społecznej.

Konopka D. (2011) Praca w systemie wartości bezrobotnych regionu białostockiego in: Przemiany pracy, postaw i ról zawodowych, D. Walczak-Duraj (ed.), Łódź, Wydawnictwo Uniwersytetu Łódzkiego: 207-218.

Kostrzewski S., Worach-Kardas H. (2008) Zdrowotne i społeczno-ekonomiczne aspekty długotrwałego bezrobocia $w$ środowisku wielkomiejskim, "Problemy Higieny i Epidemiologii", 89, 4: 504-510. 
Kostrzewski S., Worach-Kardas H. (2015) Wpływ bezrobocia na zdrowie i jakość życia osób w starszej grupie wieku produkcyjnego, "Hygeia Public Health”, 50 (2): 372-382.

Kowalczyk E. (2008) Człowiek wobec bezrobocia, "Przegląd Organizacji”, 4: 22-25.

Krajewski Z., Krugiełka A., Kujawińska A., Więcek-Janka E. (2010) Formy ograniczenia bezrobocia i analiza niedopasowania zawodowego w powiecie konińskim, Poznań, Wydawnictwo Bonami.

Kulik T. B., Pacian A., Pacian J., Janiszewska-Grzyb M. (2008) Bezrobocie a zdrowie: wybrane problemy, "Acta Scientifica Academiae Ostroviensis", 31: 5-15.

Kwiatkowski E. (2014) Bezrobocie. Podstawy teoretyczne, Warszawa, Wydawnictwo Naukowe PWN.

Latalski M., Kulik T. B., Pacian A., Skorzyńska H., Żołnierczuk-Kieliszek D. (2003) Wpływ bezrobocia na stan zdrowia i kształtowanie zachowań zdrowotnych wśród osób pozostających bez pracy, "Zdrowie Publiczne”, 113 (1/2): 174-177.

Lubińska-Bogacka M. (2011) Społeczno-edukacyjne problemy rodzin bezrobotnych, Kraków, Wydawnictwo Naukowe UP.

Miś L. (2007) Problemy społeczne: teoria, metodologia, badania, Kraków, Wydawnictwo Uniwersytetu Jagiellońskiego.

Mlonek K. (1992) Tradycje badań bezrobocia w Polsce - zagadnienia metodologiczne, "Wiadomości Statystyczne", 6: 1-6.

Murawska A. (2015) Zróżnicowanie i uwarunkowania poziomu bezrobocia w miastach wojewódzkich w Polsce, "Marketing i Rynek", 10: 216-225.

Nagel K. (2015) Relationships between unemployment and economic growth - the review (results) of the theoretical and empirical research, "Journal of Economics and Management", 20 (2): 64-79.

Nawrat R. (2001) Bezradność bezrobotnego. Wyuczona bezradność jako psychologiczny czynnik długotrwałego bezrobocia in: Psychologia społeczna $w$ zastosowaniach. Od teorii do praktyki, K. Lachowicz-Tabaczek (ed.), Wrocław, Wydawnictwo Atla 2: 187-199.

Pasikowski T. (2000) Stres i zdrowie, Poznań, Wydawnictwo Fundacja Humaniora.

Paul K. I., Moser K. (2009) Unemployment impairs mental health: Meta-analyses, "Journal of Vocational Behavior", 74: 264-282. 
Pilc M. (2014) Determinanty bezrobocia w Polsce w latach 1993-2012, Warszawa, Wydawnictwo CeDeWu.

Poprawa R. (2008) Samoocena jako miara podmiotowych zasobów radzenia sobie i szczęścia człowieka in: Psychologia zdrowia w poszukiwaniu pozytywnych inspiracji, I. Heszen, J. Życińska (eds.), Warszawa, Wydawnictwo SWPS “Academica”: 103-121.

Sęk H., Cieślak R. (2004) Wsparcie społeczne - sposoby definiowania, rodzaje i źródła wsparcia, wybrane koncepcje teoretyczne in: Wsparcie społeczne, stres $i$ zdrowie, H. Sęk, R. Cieślak (eds.), Warszawa, Wydawnictwo Naukowe PWN: 11-28.

Skłodowski H., Kucharski K. (2007) Wpływ cech osobowości na efektywność zawodowq, w: H. Skłodowski, E. Stawasz, Psychologiczne wyznaczniki efektywności poszukiwania pracy $i$ samozatrudnienia $w$ regionach zmarginalizowanych, Łódź, Wydawnictwo Uniwersytetu Łódzkiego: 127-248.

Stochmiałek J. (2015) Kryzysy życiowe osób dorosłych. Refleksje andragogiczne i edukacyjne, Warszawa, Wydawnictwo Uniwersytetu Kardynała Stefana Wyszyńskiego.

Ślebarska K. (2010) Wsparcie społeczne a zaradność człowieka w sytuacji bezrobocia, Katowice, Wydawnictwo Naukowe "Śląsk".

Ślebarska K. (2017) Droga do pracy. Proaktywne radzenie sobie a poszukiwanie zatrudnienia i adaptacja do nowego miejsca pracy, Katowice, Wydawnictwo Uniwersytetu Śląskiego.

Śmilgin M. (2006) Indywidualne i społeczne skutki bezrobocia na tle globalizacji, "Nierówności Społeczne a Wzrost Gospodarczy", 8: 423-434.

Terelak J. F. (2017) Stres życia. Perspektywa psychologiczna, Warszawa, Wydawnictwo Uniwersytetu Kardynała Stefana Wyszyńskiego.

Walczak R. (2000) Obraz siebie u kobiet długotrwale bezrobotnych, Lublin, Towarzystwo Naukowe KUL.

Waters L. E., Moore K. A. (2002) Predicting self-esteem during unemployment: the effect of gender, financial deprivation, alternate roles, and social support, "Journal of Employment Counseling", 30: 171-189.

Werner I. (2009) Poczucie koherencji a praca in: Człowiek w kontekście pracy. Teoria - empiria - praktyka, M. Piorunek (ed.), Toruń, Wydawnictwo Adama Marszałek: 107-128.

Wiatrowski Z. (2005) Podstawy pedagogiki pracy, Bydgoszcz, Wydawnictwo Akademii Bydgoskiej im. Kazimierza Wielkiego. 
Wolska-Długosz M. (2012) Aspiracje edukacyjne i zawodowe licealistów, Kielce, Wydawnictwo Uniwersytetu Jana Kochanowskiego.

Wołk Z. (2009) Kultura pracy, etyka i kariera zawodowa, Radom, Wydawnictwo Naukowe Instytutu Technologii Eksploatacji.

Zagożdżon P., Ejsmont J. (2008) Jakość życia zwiq̨zana ze zdrowiem u bezrobotnych, "Problemy Higieny i Epidemiologii", 89 (4): 498-503.

Zalewska A. M., Jaros R. (2008) Społeczne i psychologiczne uwarunkowania bezrobocia - posiadane przekonania a sytuacja na rynku pracy, Łódź, Wydawnictwo "Piątek Trzynastego".

Żółtaszek A. (2016) Analiza społecznych i indywidualnych uwarunkowań bezrobocia w Polsce, "Polityka Społeczna", 1: 27-34. 